\title{
Who defines 'whole': an urban political ecology of flood control and community relocation in Houston, Texas
}

\author{
Kevin A. Lynn ${ }^{1}$ \\ Troy University at Montgomery, USA
}

\begin{abstract}
Even if public agencies sponsoring projects like flood alleviation have the best of intentions for relocated households, there may still be residents who do not agree with being forced to move. Federal relocation policy in the US has been, and continues to be, concerned primarily with housing economics and financial compensation. And yet, residents subject to relocation continue to express other concerns. The public agency responsible for relocation from flood-prone Kashmere Gardens in Houston, TX has promised to make households 'whole' in terms of finding new housing that is no more expensive (in terms of rent, mortgage payments, and equity) than vacated homes. While these considerations are important, this article illustrates how public agencies need to expand how they define 'whole.' Interviews with 53 households affected directly or indirectly by relocation show that the following factors need consideration when subjecting households to involuntary relocation: (1) suitability of new housing, (2) perceived competence of relocation specialists, (3) the relocation planning process, and (4) potential health issues for relocated households.
\end{abstract}

Key Words: Kashmere Gardens, Houston, Uniform Relocation Act (URA), flood control infrastructure, urban political ecology

\section{Résumé}

Même si les organismes publics qui parrainent des projets comme l'atténuation des inondations ont les meilleures intentions pour les ménages déménageurs, il peut y avoir des résidents qui ne sont pas d'accord pour être forcés de déménager. La politique nationale de relocalisation aux États-Unis a toujours été, et continue d'être, principalement concernée par l'économie du logement et la compensation financière. Et pourtant, les résidents soumis à des déménagements continuent d'exprimer d'autres préoccupations. L'agence publique responsable de la réinstallation des Kashmere Gardens à Houston, TX, a promis de rendre les ménages «entiers» pour trouver de nouveaux logements qui ne coûtent pas plus cher que les maisons libérées (en termes de loyer, de paiements hypothécaires et d'équité) . Bien que ces considérations soient importantes, cet article illustre comment les organismes publics doivent élargir leur façon de définir «entier». Les entretiens avec 53 ménages touchés directement ou indirectement par relogement montrent que les facteurs suivants doivent être pris en considération lorsqu'ils soumettent les ménages à une réinstallation involontaire: (1) l'adéquation des nouveaux logements, (2) la compétence perçue des spécialistes de la réinstallation, (3) le processus de planification de la réinstallation, et (4) problèmes de santé potentiels pour les ménages déménagés.

Mots clés: Kashmere Gardens, Houston, Uniform Relocation Act (URA), infrastructure de lutte contre les inondations, écologie politique urbaine

\section{Resumen}

Aún con las mejores intenciones por parte de las agencias públicas que respaldan proyectos que requieren reubicación doméstica, hay residentes que podrían no estar de acuerdo con la reubicación. Las políticas federales de reubicación históricamente han estado y siguen estando preocupadas con la economía de la vivienda, pero los residentes sujetos a la reubicación siguen expresando otros intereses. La agencia pública que se destaca en este artículo, ha prometido hacer más hogares "integrales" en términos de encontrar nuevas

\footnotetext{
${ }^{1}$ Dr. Kevin A. Lynn, Lecturer, Social Sciences, Troy University at Montgomery, Alabama, USA. Email: klynn "at" troy.edu. Thanks to Dr. Stephen Perz, University of Florida who introduced me to political ecology and provided guidance on this article. Also, thanks to the anonymous reviewers who provided helpful comments on earlier drafts.
} 
viviendas que no sean más costosas (cuando costoso se relaciona con el alquiler, los pagos de la hipoteca y fomentar la equidad en una casa), que enfocarse en desalojo de viviendas. Mientras que estas consideraciones son importantes, este artículo ilustra cómo las agencias públicas pueden necesitar expandir cómo definen lo "completo". Las entrevistas con 53 hogares afectados directa o indirectamente por la reubicación, muestran que (1) la pertinencia de nueva vivienda, (2) la capacidad percibida por los especialistas en reubicación, (3) el proceso de planificación para reubicar, y (4) los temas de salud de hogares potenciales reubicados necesitan consideración cuando estos son sujetos a reubicación involuntaria.

Palabras clave: Kashmere Gardens, Houston, Acta Uniforme de Reubicación (URA), infraestructura de control de inundación, ecología política urbana.

\section{Introduction}

More than half of humanity now lives in urbanized areas (Heynen 2014). Researchers in urban political ecology (UPE) have argued that we are now in the "urban century." Of particular importance for UPE is the fact that the majority of the world's urbanized or developed areas are in coastal regions (Keil 2003; National Academy of Sciences 2006; United Nations Office for Disaster Risk Reduction 2012). In such areas, hazards including tropical storms, hurricanes, and floods all provide unwelcome reminders of nature's dark side.

UPE research has looked at a variety of water and water-infrastructure related issues in cities. Example include studies focused on access to water (Smith 2002; Swyngedouw 2009), water as an amenity, and an element of neighborhood identity (Hagerman 2007), and water as a locus for ports (Bunce and Desfor 2007). UPE has also investigated water as a destructive force in crises in Los Angeles (Davis 1998) and on the Mexican/US border (Collins 2010). Traditional political ecology (PE) research has looked at large-scale infrastructure projects that have involved relocating local peoples (Colchester 1993; Griffiths 2005; Heming et al. 2001). Highways, ports, dams, airports, and other installations often require relocating communities involuntarily, and PE research has highlighted the resulting contention and protests against governments and other outsiders. This article brings together urban studies and PE in an urban political ecology framework by focusing on the relocation mandated by an urban water-control project. I focus on Houston, a large coastal city well known for its significant social inequalities and vulnerability to flood risk. Specifically, I take up the case of Project Hunting, a large-scale flood-control project that requires relocating some residents of Kashmere Gardens, a largely minority community. To government and other outsiders, Project Hunting will help protect Kashmere Gardens, but the prospect of forced relocation has caused others to question who will benefit and who will suffer.

The public agency in charge of the relocation effort (Harris County Flood Control District) initially sought to relocate 800 households. Through a community planning process and with some community input, the public agency reduced the number of relocated households to 40 . The agency has promised the relocated households market prices for their homes and money to cover moving costs. A spokesperson for the agency also said, "We promise they'll be made whole again" (Moran 2010). Reducing the number of relocated households so much is a substantial move toward maintaining the community, but there are still many households that want to stay. These households cannot be 'made whole' after receiving compensation. As in any relocation project, residents are attached to place, an attachment that financial compensation may or may not adequately offset. While wholeness certainly involves accounting for households' financial problems, it also means considering their attachment to place and the potential for differential treatment of different parts of a community.

In the remainder of this article, I will first review examples from previous work in traditional political ecology that examines infrastructure and relocation. They are relevant because they highlight how outsiders to communities tend to undervalue place attachments by community residents when imposing involuntary relocation. I then turn to issues of urban infrastructure and relocation in the United States as a means to integrate urban studies and PE in a UPE approach. I describe my research method: a qualitative approach that allows us to understand resident perspectives on relocation and being made whole. The concluding discussion will show how my article contributes to UPE. 


\section{Political ecology and relocation}

Traditional PE has focused on relocation because it occurs in a variety of contexts and catalyzes social and ecological change. Relocation often brings changes of fortune for resettled groups vis-à-vis other groups. But the national governments that usually oversee relocation projects are outsiders that may not perceive these social ramifications. A political ecology analysis highlights how a government may forcibly relocate a group away from an important natural resource, leading to significant disadvantages for them (Johnson 1989). One key kind of relocation discussed in traditional PE is carried out to improve conservation and preservation. International environmental NGOs incentivize governments in the Global South to create protected areas and new parks, to nationalize forest reserves, and to implement stricter conservation rules on private lands under biodiversity or watershed-management programs. One might ask whether relocation, resettlement, or displacement actually improve conservation and preservation. PE research has shown that when people are relocated from their environments, hunters, poachers, migrants, and business interests come in and may be responsible for increasing environmental degradation or species loss (McElwee 2006). Removing people from their traditional environments sometimes makes it easier for business interests more threatening to the environment to extract resources (McElwee 2006).

Political ecologists have also highlighted the history of relocating native peoples. Political economies dominated by natural-resource extraction industries, and a political elite that favors them, tend to dismiss the concerns of native peoples (Colchester 1993). Relocation policies often reflect broader efforts to criminalize native peoples who assert claims to territory. In protest, native peoples at times block the roads created by resource-extraction interests like mines and logging concessions (Colchester 1993). During the colonial era, for example, the British navy used cannons to attack native settlements when they hindered their resource extraction interests, and the colonial powers considered native peoples who refused to move to be squatting on their own land. Hunters and gatherers in protected areas can still be treated as poachers as they practice traditional livelihoods (Colchester 1993).

Large-scale infrastructure projects are frequently the rationale for relocation initiatives. Numerous dams have been built around the world, and large ones typically require relocating people from areas to be inundated with water from dam-related reservoir construction (Heming et al. 2001). Such relocation efforts often lead to hardship for those who were relocated involuntarily (Cernea 2006; Colchester 1993; Heming et al. 2001; McElwee 2006; Scudder 1993). Relocatees who move to cities on the promise of new jobs find that people like themselves are the first to be laid off during economic downturns. Local officials often misspend and steal money their national government had appropriated with the intention of helping relocatees. Those who are relocated to rural areas are often granted land that is unsuitable for agriculture, due to steepness, difficulty of access, or lack of topsoil. In these instances, migrants have harvested lumber and firewood from forests (Heming et al. 2001). For these and other reasons, in many cases, relocated people make illegal attempts to move back to their original homelands even when their former homes are occupied, partially developed, or underwater.

Negative impacts occur from relocation because state actors inadequately administer it, and discount the importance of attachment to place. Research on the prospects for relocated people is vital (Griffiths 2005). The World Bank was criticized for supporting projects that have not fully acknowledged the concerns of indigenous peoples. It now includes relocatee input in its planning for large scale infrastructure, and has created standards for relocation (after being pressured by groups such as Cultural Survival, World Wide Fund for Nature, and Conservation International). One of the continuing points of contention is the principle that relocation should leave no community worse off (Griffiths 2005). To conform to that principle, the World Bank tries to force national governments to abide by it in their relocation plans.

The United Nations now insists infrastructure projects abide by the following standards:

- Infrastructure project sponsors and project managers should allow affected communities to participate in critical relocation and implementation decisions (e.g., site selection, identification of basic needs, settlement planning, and housing designs)

- Communication between affected communities and state actors should be frequent and transparent, and mechanisms to resolve grievances need to be effective 
- Social, environmental, and hazard-risk assessments must confirm that risk cannot be mitigated in the old location, and state actors must assure the community that the relocation site is suitable

- Governments must adequately fund relocation and attempt to assuage its economic impacts over a reasonable period

- Lastly, project feasibility analysis must show that emotional, spiritual, and cultural attachment to the old site is not excessively high. (Jha, Miner and Stanton-Geddes 2013; World Bank 2010)

\section{An urban political ecology of relocation}

To justify a new UPE of flood control and relocation, I will review the research on relocation to consider the various types of infrastructure constructed in urban settings. I will then meld that research with concerns in the study neighborhood.

Relocation carried out in urban areas of the postwar United States shared some features with the Global South. Like the World Bank, the US federal government has created a set of standards for relocating people during development projects. In particular, it emphasizes financial assistance. but this disregards other concerns faced by relocatees - especially people of color-most notably place attachment and emotional suffering, what de Vries calls attending to care (de Vries 2017; Maldonado 2014).

After WWII, millions of households in the United States were relocated for urban renewal, slum clearance, public-housing development, and interstate-highway construction (Hartman 1971; Martin 1983). While urban relocation projects were supposed to serve the public interest, research shows that not everyone benefited. Involuntarily relocated lower middle-income and poor black households bore the brunt of the costs (Sterne, Kaufman, and Rubenstein 1977). Congress passed multiple Acts in the 1940s, 1950s, and 1960s to address this issue, which resulted in an agglomeration of complex and confusing rules. The Uniform Relocation Assistance and Real Property Acquisition Policies Act of 1970, also known as the Uniform Relocation Act (URA), intended to supersede older Acts to provide a comprehensive set of benefits to those who are involuntarily relocated or have real property taken away through eminent domain, as a result of a project supported with Federal financing (United States Department of Housing and Urban Development 2015a). The Act was later amended in 1987.

The URA seeks to:

(1) provide uniform, fair, and equitable treatment of persons whose real property is acquired or who are displaced in connection with federally funded projects;

(2) ensure relocation assistance is provided to displaced persons to lessen the emotional and financial impact of displacement;

(3) ensure that no individual or family is displaced unless decent, safe, and sanitary housing is available within the displaced person's financial means;

(4) help improve the housing conditions of displaced persons living in substandard housing; and

(5) make it easier for public agencies to acquire displaced persons' property by agreement and without coercion. (United States Department of Housing and Urban Development 2015a)

The URA pursues the last objective by outlining the following public agency responsibilities:

(1) appraising property before negotiations;

(2) inviting the property owner to accompany the appraiser during the property inspection;

(3) providing the owner with a written offer of just compensation and a summary of what the new owner is acquiring;

(4) paying for property before possession; and 
(5) reimbursing expenses resulting from the transfer of title, such as recording fees and prepaid real estate taxes.

Acquisitions that cause residents to be displaced must meet the following requirements:

(1) provide relocation-advisory services to displaced tenants and owner-occupants;

(2) provide a minimum ninety days' written notice to vacate prior to taking possession;

(3) reimbursing moving expenses; and

(4) providing payments for the added cost of renting or purchasing comparable replacement housing. (United States Department of Housing and Urban Development 2015a)

While the URA emphasizes household finances and property-owner rights, monetary compensation may not be suitable to address certain community and social effects. The social impacts are likely to be especially significant for communities of color. Political outsiders who make plans for relocation often have inaccurate impressions of their needs and priorities, overlooking attachment to neighborhoods, and strong social ties. Relocation can be especially disruptive socially and damaging emotionally, with or without financial compensation (de Vries 2017; Falk 2004; Stack 1974; Yosso 2006). Black families are more likely to live near relatives who provide child care and help with transportation. Relocated families of color commonly suffer from depression, isolation, regret, and resentment due to a sense of loss of control over their lives (Rohe and Mouw 1991). Finally, many relocatees find their housing situation does not improve significantly. While the worst housing is by definition substandard, it is usually also the cheapest, meaning some involuntarily relocated households end up with higher housing costs (Hartman 1971).

Interstate highway planning often does not take into account the social impacts of disrupting neighborhoods, especially black ones. This is not surprising considering that housing and community experts from the US Department of Housing and Urban Development (HUD) have historically discounted relocatee concerns. One should not expect transportation engineers (or any other type of engineer) to do a better job in handling household and community concerns (Roberts 1973).

HOPE VI was a Housing and Urban Development revitalization program started in 1993 to address social problems like racial and economic segregation that had arisen in earlier public housing developments. One concern was that many first-wave public-housing developments in the urban United States were poorly designed and built, which exacerbated social problems (United States Department of Housing and Urban Development 2015b). HOPE VI public-housing redevelopment projects sought to not only rehabilitate buildings and property but to also create new communities of households of varying income levels. This included deconcentrating poor families in public housing that was being rehabilitated and relocating some of them to middle class communities (Cunningham 2004; Goetz 2010; Manjarrez et al. 2007).

HOPE VI conducted new research on the effects of relocation. Studies highlight the link between physical surroundings and resident health, comparing HOPE VI relocatees before and after relocation (Manjarrez et al. 2007). Health survey respondents reported much worse health than the general population, which did not improve after relocation. Obesity, diabetes, arthritis, asthma, depression, hypertension, and strokes all had a higher incidence among HOPE VI survey respondents before as well as after relocation, despite the better housing. Those subject to involuntary relocation also had higher mortality rates than comparison groups.

Thus, an urban political ecology of relocation exists, rather different to the classic studies of population displacement in the global South. Outside entities, typically government agencies, impose relocation requirements. Outsider understanding of the needs and concerns of communities to be relocated is often limited, and program administration is often inadequate, whether handled by engineers or housing experts. The tendency is for racial or ethnic minorities or other disadvantaged groups to be identified for relocation, hopefully with lower economic and political costs. Just as in the Global South, relocatees lose financially. More generally, displaced people encounter difficulties adapting to their new housing sites. But in rural political ecology, research on community concerns highlights the loss of livelihoods, whereas urban political ecology focuses more on negative health outcomes. 
The last point motivates further inquiry. While attachment to place is widely documented, and while UPE research finds that financial compensation is insufficient to avoid negative health outcomes, it remains unclear how urban relocatees themselves - especially people of color-view financial compensation and its limitations. More broadly, it is unclear how people of color facing relocation articulate the various possible shortcomings of financial compensation. I focus here on qualitative accounts of how those threatened with relocation understand financial compensation and its inadequacies, in light of their needs and concerns. I provide firsthand accounts of people of color, in order to reveal the broader array of needs facing urban relocatees.

\section{Kashmere Gardens and Project Hunting}

With a population of 2.3 million, Houston, Texas, is the fourth-largest city in the United States and a large and growing coastal city. With a population around 6 million, the Houston MSA (metropolitan statistical area) is the fifth-largest in the United States and is by far the largest in the Gulf Coast region, at more than twice the size of Tampa-St. Pete's-Clearwater (with a population of 2.8 million). The Houston MSA has experienced one of the highest population growth rates among the ten largest cities in the United States, surpassed only by San Antonio, Texas and Phoenix, Arizona.

Houston is also the economic leader of Gulf Coast cities. Only New York City is home to more Fortune 500 company headquarters. Of the twenty-six Houston companies in the Fortune 500, thirteen are in petroleum exploration, production, or processing (Jankowski et al. 2015). This has led the Port of Houston to become one of the busiest in the world, most frequently shipping petroleum products. When ranked by shipped short tonnage, the Port of Houston is second in the United States and on the Gulf Coast, outranked only by the Port of South Louisiana (Port of Houston Authority 2015).

While Houston's location on the Gulf Coast has brought economic prosperity, it also floods periodically. Houston has twenty-two bayous (its nickname is the Bayou City) and other waterways that extend for over 2,500 miles $(4,023 \mathrm{~km})$ throughout the city. This watery environment floods regularly, especially during extreme weather events. An illustrative example is Tropical Storm Allison (TSA) in 2001. TSA arrived in Houston on June 4 and did not dissipate until June 18, two weeks later. Over 70,000 houses were flooded, with more than 2,700 destroyed, and twenty-two people died (Ivey 2002).

While such damage can be explained in part by Houston's location, other factors also contribute, including the politics of urban planning. Houston is well known as the largest city in the United States without a zoning ordinance. It does have a planning department, but it is mostly concerned with short-term problems related to specific projects. The lack of planning implies that urban development in Houston has been largely spontaneous. One result of urban expansion is the increase in impervious cover (IC), which can worsen flood risk and affect coastal urban ecosystems (Scheuler 1987; Scheuler et al. 2009). Imperviousness occurs primarily in two forms: on rooftops and along transport systems (roads, driveways, sidewalks, and parking lots). Imperviousness reduces the soil's ability to absorb storm water and speeds up flow through a watershed. Houston-area soil is rich in clay and the local topography is rather flat, exacerbating flooding after heavy rains (Harris County Flood Control District 2015a). The presence of impervious cover often means a lack of trees, which can slow storm water rise (Jha, Bloch, and Lamond 2011). As Greater Houston's population has grown, so has its impervious cover.

Flood control has become a major issue for the city. Houston was founded at the confluence of Buffalo Bayou and White Oak Bayou in 1836. After large floods in 1929 and 1936, the City of Houston requested flood control assistance from the US Army Corps of Engineers (USACE). This led the Harris County government leadership to create the Harris County Flood Control District (HCFCD) in 1937. The HCFCD serves as the local partner for USACE flood-control projects (Harris County Flood Control District 2015a). The earliest flood control Acts provided USACE assistance to specific projects on the Mississippi and Sacramento rivers. The USACE's mission was extended to include flood control for the entire United States with the Flood Control Act of 1936 (O'Neill 2006; US Army Corps of Engineers 1998).

The HCFCD seeks to manage twenty-two watersheds that flow through Houston and approximately eighty other incorporated and unincorporated municipalities. Flood-control infrastructure and technology partially funded and implemented by the USACE have allowed for the growth of the Houston metropolitan 
area. The HCFCD also works on the water quality and ecology of the bayous as well as constructing and promoting projects that use them for recreational amenities (Harris County Flood Control District 2015a). While Houston may not be known for long-range planning, the HCFCD has been involved in it since its founding (Feagin 1988).

The Hunting Bayou watershed encompasses a thirty square-mile $\left(78 \mathrm{~km}^{2}\right)$ drainage area with forty-five miles $(72 \mathrm{~km})$ of open streams (Harris County Flood Control District 2015b). Project Hunting is a flooddamage reduction project first announced in 1990 that will widen and deepen about four miles $(6.4 \mathrm{~km})$ of Hunting Bayou, replace or newly construct more than twenty bridges, and excavate a 300 million gallon (1,364 m litre) storm water detention basin on a seventy-five acre (30 ha) site (Figure 1). The width of Hunting Bayou will be doubled (typically from approximately 100 feet to approximately 200 feet, 30-61 m). Project Hunting will also require the relocation of eighty households (Harris County Flood Control District 2015c).

Hunting Bayou runs through Kashmere Gardens neighborhood, and infrastructure improvements and 'soft' approaches (housing and other property acquisitions, as well as household relocations) are planned to mitigate flood risk. Some residents of Kashmere Gardens are opposed to being relocated (Moran 2010). Their neighborhood lies between an industrial corridor and a railroad line and is subjected to pollution from the corridor's petroleum refineries and solid-waste incinerators, and there is illegal dumping in the watershed, as environmental justice campaigner Bob Bullard exposed (Bullard 2000a, b). In spite of these drawbacks and the flooding threat, the residents love their neighborhood enough that they rejected HCFCD relocation with compensation.

When considering addressing natural risks through infrastructure engineering, civil engineers assess the social vulnerability of a threatened community by looking at its racial makeup, its income, its educational attainment, and its dependent populations (Bedient 2012). Kashmere Gardens is much more socially vulnerable than Houston as a whole. Approximately $24 \%$ of Houston's residents identify as black, $44 \%$ as Latino, and $26 \%$ as white alone. In Kashmere Gardens, $77 \%$ of the residents are black, $21 \%$ Latino, and 0.4 $\%$ white alone. Houston's median household income is US $\$ 45,000$, while Kashmere Gardens' median household income is just US $\$ 22,000$, with $43 \%$ of households having incomes less than US $\$ 15,000$. The residents have lower levels of educational attainment: only $52 \%$ have finished high school or more compared with $75.4 \%$ for all of Houston. More individuals are dependents as a percentage: $30 \%$ of Kashmere Gardens residents are under the age of eighteen (27\% across Houston). Some $16 \%$ are over the age of 64 (10.3\% for Houston as a whole) (City of Houston Planning and Development Department Public Policy Division 2010).

HCFCD engineers say the Kashmere Gardens homes lie in a 100-year floodplain that flooded in 1979, 1980, 1983, 1989, 1993, 1994, 1997, 1998, 2006, and 2007 (Aecom Technical Services 2014, Figure 1). Storm Allison in 2001 caused 22 fatalities across the County with 30,000 people in temporary shelters, and there was more damage in in 2015 and 2016 (when there were 8 deaths in Harris County, and 1,800 rescues). But the residents who want to stay feel their homes are targeted for acquisition because they are relatively cheap, and they lack resources to fight back. Approximately 91,000 people live in the Hunting Bayou watershed, 12,000 of whom live in Kashmere Gardens (Harris County Flood Control District 2015b). But only forty households need to be involuntarily relocated for Project Hunting, all in Kashmere Gardens. These voluntary and involuntary relocatees have rights under the Uniform Relocation Act as well as under state and local laws (Aecom Technical Services 2014).

To construct the US\$176 million project and remove a floodplain from a socially vulnerable community, the HCFCD needs to acquire additional land or rights-of-way (Harris County Flood Control District 2015c). The acquisition process has begun. The HCFCD holds community meetings months or even years in advance of projects that will widen detention basins or bayous. These meetings are held to alert affected communities about HCFCD plans and to request community members' feedback. Once the HCFCD decides it needs to acquire land, the Right of Way Division of the Harris County Public Infrastructure Department creates a list of parcels it must purchase (Saucier 2003). The Right of Way Division asks the Harris County Commissioners' Court to declare the required acquisitions as public necessities. The Division obtains title reports on the parcels to ascertain ownership, as well as alerting owners by mail that their property is needed for an HCFCD project and that they will soon be contacted by an appraiser to determine 
property value. Soon afterwards, the Right of Way Division makes an offer to property owners. Property owners have forty-five days to accept, negotiate a better price, or to refuse to move. If they refuse, a condemnation process begins. ${ }^{2}$ Right of Way Division relocation specialists usually show two or three home options to those households subject to buyouts (Harris County Flood Control District 2015c) and offer relocation assistance to those subject to mandatory buyouts. This includes extra money to cover the difference in value between the HCFCD-acquired home and the new one. The HCFCD reimburses moving expenses for households that move on their own, or covers these expenses if they contract with movers. The HCFCD also covers differences in interest payments between old mortgages and new ones (Harris County Flood Control District 2015c).

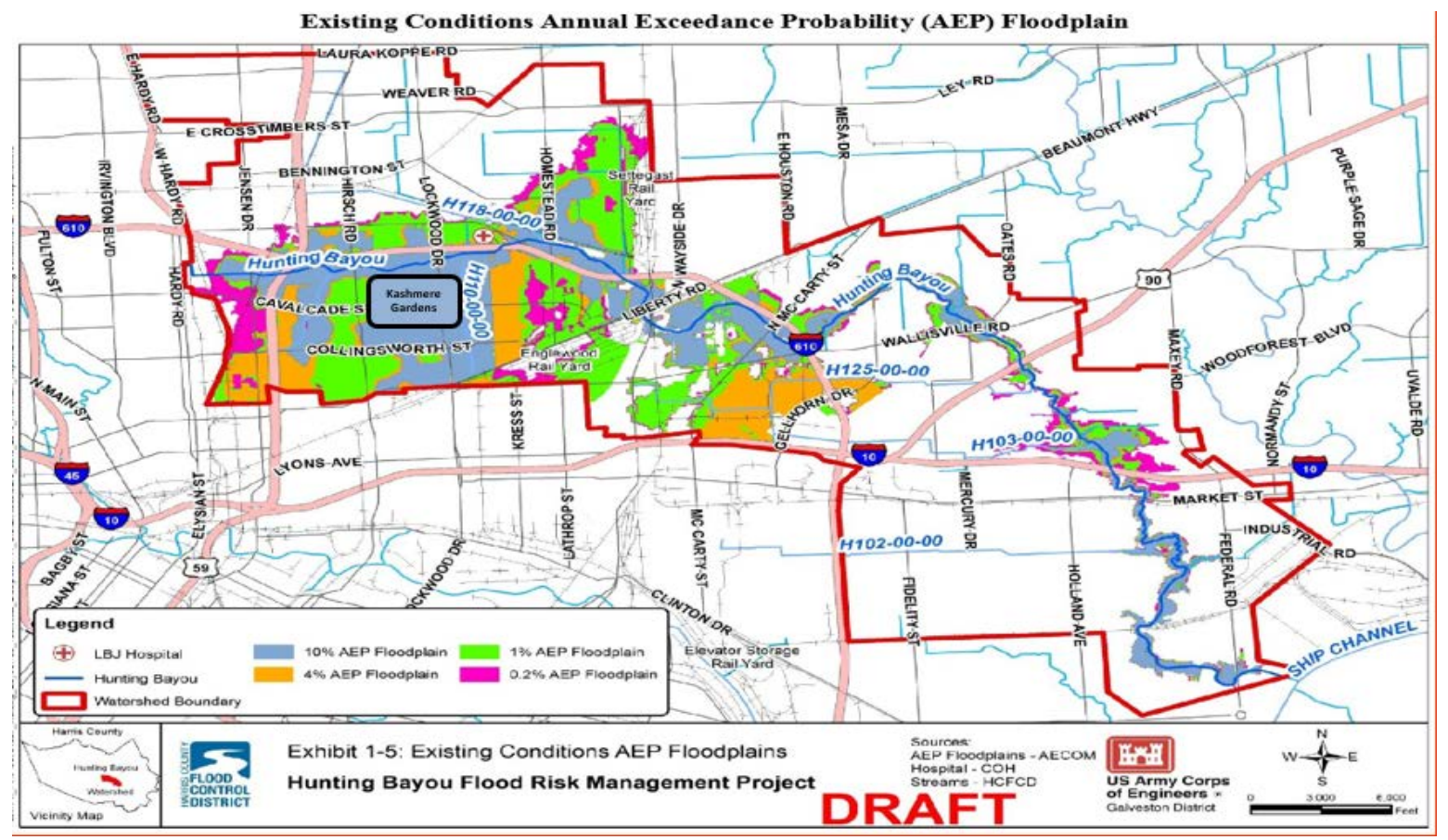

Figure 1: Probability of flooding, Kashmere Gardens neighborhood highlighted (approx. 7x3km), situated north-east of Houston downtown. Source: Hunting Country Flood Control District.

\section{Fieldwork methodology}

To understand resident perspectives on financial compensation for relocation, I undertook qualitative research to acquire in-depth information from residents in the community. ${ }^{3}$ This complements previous quantitative research by Zhang (2010) that showed Harris county residents were more concerned about flood risk than they were about extreme weather risk (hurricanes and major storms) and petrochemical pollution from Houston-area industry. I focused on resident feelings, perceptions, and meanings constructed around community, flood risk, and relocation.

I interviewed three groups of residents and former residents of Kashmere Gardens, including those who voluntarily accepted relocation assistance, those who were involuntarily moved, and residents who were not required to relocate. I did not limit my research to the 40 households subject to involuntary relocation as I

\footnotetext{
2 "Condemnation via eminent domain" means the government takes ownership of the property in a condemnation action. Just compensation to the owner(s) is then determined in court.

3 'Community' means those who live in Kashmere Gardens, regardless of race.
} 
wanted community-wide perspectives, using data collected from as many household representatives as possible willing to work with me.

I identified potential interviewees by attending numerous weekly church Bible studies, by working out of a local library branch, and by visits to a city-operated senior community center. After preliminary conversations, I was able to provisionally categorize residents. I started by identifying the ten people who would serve as my initial interviewees. I then employed a snowball-sampling technique (Goodman 1961) to identify additional residents in each of the three groups. This took advantage of the dense social networks in the community and was particularly useful for making contacts with those residents who had already been relocated from Kashmere Gardens.

I accumulated a total of fifty-three cases, more or less evenly spread among the three groups. I spoke with fourteen homeowners in favor of being relocated, seventeen who were not in favor of being relocated, and twenty-two who were not subject to relocation. The majority of the interviewees were female (56 \%), they ranged in age from thirty-one to seventy-five, and all but six were homeowners. Their residency in the neighborhood ranged from twelve to forty-six years. African Americans made up $90.6 \%$ of the interviewees, and the remaining $9.4 \%$ were Latinos. I made no attempt to obtain a sample from which to make statistical inferences.

The interviews were semi-structured with a list of key themes guiding conversations. Interviewee responses guided the subsequent questions. I took special care seek clarifications, as I was not sure if followup interviews would be feasible. Interviews started with general discussion of community, perceived flood risk, thoughts on relocation, and Project Hunting. I also asked about communications with the HCFCD. I recorded interviews and transcribed them. I used structural coding to illuminate key themes in the data, which also identified emergent themes beyond those I initially contemplated (Guest et al. 2012; MacQueen et al. 2008; Namey et al. 2008; Saldaña 2012). I combined coded segments for more detailed analysis, then aggregated key themes into categories that reflected interviewees' concerns.

To document feelings of place attachment I asked interviewees how long they had lived in Kashmere Gardens, and interviewees discussed whether and how Kashmere Gardens was important to them for providing a support network or otherwise helping them emotionally or socially. Perceptions of flood risk mattered because they were likely to influence attitudes towards risk mitigation and relocation. Knowing the interviewee's place in the three groups helped to focus the discussions. The terms of relocation offered by the HCFCD were discussed in detail, and whether the financial terms were just and adequate. This discussion permitted respondents to elaborate on other aspects of relocation than financial packages.

\section{Qualitative findings}

HCFCD aims to make the relocated households 'whole', but this is framed in terms of housing suitability and housing economics. While Project Hunting is not explicitly an economic development project, a federal government agency (USACE) and its local partner (HCFCD) are using their power to alter the environment and impose a new order on the lives of Kashmere Gardens residents. That power is constrained somewhat by the URA, which arose from problems with involuntary relocations in order to construct roads and affordable housing, and to clear slums. Kashmere Gardens residents talked about the possibility of being made 'whole' in four domains, discussed in turn:

(1) suitability of housing

(2) perceived competence of relocation specialists

(3) the relocation planning process, and

(4) potential health issues.

\section{Place attachment and relocatee views on new housing}

Kashmere Gardens residents who had yet to be relocated were rightfully concerned about the affordability and size of housing in their new neighborhoods. Location was also an issue. One resident said: 
My husband and I purposefully paid off our mortgage early so that we wouldn't have to worry about it. That was many months of double mortgage payments. We could have a lot more fun with that money. But we did what we had to do. Now they're taking our home from us. I've been to many houses in many neighborhoods throughout Houston and the 'burbs, but it just doesn't seem like you get as much for your money unless you're way out to where they don't even have paved streets. I like having my place-not too big, not too small. I hope I won't have to get rid of any of my furniture and other things. I got a lot of memories here.

One other resident facing relocation said:

The thing for me is, sometimes all my grandkids will stay with me, and I need a place that can hold us all. They sleep over. Then we all get up, eat breakfast, and walk to church. I can't do that if I want to walk to the same church but I've been moved away. I want them all to always know they [grandchildren] will have room with me if they need it. The ones who don't drive yet but old enough to take the city bus all know how to get here by bus too.

The relocatees spoke positively about their new places but missed their Kashmere Gardens homes as well. Said one relocatee, "I got a nice place, but it's just not the same. I don't miss the flooding, which I guess was the point of being moved in the first place. But it doesn't feel like home yet." One who was a renter in Kashmere Gardens and continued renting after moving, said:

I appreciate my new place. It's not real old like my apartment was here. I wonder why they never built apartments like mine in Kashmere Gardens. If they did, I might want to come back. There is nothing so nice about the new neighborhood—notice that I didn't say 'my' neighborhood—-that would keep me there if I could get a similar apartment in Kashmere Gardens.

Another former Kashmere Gardens resident who missed their former neighborhood said:

I wish I could come back to Kashmere Gardens. It wasn't perfect, and there are a few raggedy houses and ugly spots, but there is something satisfying about being able to walk around your neighborhood when the weather's nice and say hello to a good number of people you know. I even miss walking to the Korean grocery store in the neighborhood. Even though it is owned by Koreans, they [the owners] have certain things that people in the neighborhood really like for both the black people and the Mexican people. It's little things like that that make you feel like a neighborhood is your own.

Those who sacrificed to qualify for a mortgage, to buy a home, and even pay off their mortgages demonstrated feelings of disgust for the HCFCD and Project Hunting. I observed fear in those yet to be relocated about how much they would receive. These fears were not centered around the status of a house, but its sentimental value and how they could use it. House size and location affect the number and type of guests you can have. No one spoke of Kashmere Gardens as if it was heaven on earth, but many intimated that the neighborhood and its houses served many of their needs. Federal relocation and housing policy has put a premium on racially and economically integrated neighborhoods, which explicitly and implicitly discounts the experiences of those who live voluntarily in neighborhoods that policymakers find far from ideal.

\section{Resident experiences with relocation specialists}

The literature on involuntary relocations and environmental justice discusses many difficulties that communities have with project engineers in relocation situations. The HCFCD uses relocation specialists who would perhaps be more empathetic to individual household needs than engineers. As we have noted, being 'made whole' entails more than financial compensation, and wholeness considerations arise from connections 
to a particular house and to the neighborhood. Relocation specialists must address these concerns. Relocatees expressed satisfaction and complaints about the specialists.

Those who have yet to be relocated said they were sometimes uncertain which public agency the relocation agents were from. One resident said, "I know they said something about being with the county, but they didn't say they were with the flood-control people." This is not surprising, because the relocation specialists are actually employees of the Harris County Public Infrastructure Department, not the HCFCD. Another cause of concern for the not-yet-relocated was their unreliability in providing information: "Sometimes you'll ask them something that they don't know the answer to off hand and they say they'll get back to you but they never do", one person said. The relocation specialists appeared not to commit to specific dollar amounts for moving expenses, rental assistance, or home acquisition. If an exact dollar amount is stated early in the consultation process but the actual budget comes in lower, that household may feel misled. Another relocatee stated:

All I wanted to know was how much I had coming to me. But they couldn't or wouldn't tell me. I got tired of dealing with them. They tried to explain how the amount of money I would be getting would be figured out, but it was confusing to me. I asked if I could end up with a higher house note, and they wouldn't tell me.

Despite those concerns, the relocated interviewees expressed some satisfaction. One noted, "She was real nice. Not everything went as planned during the move, but nobody's perfect." Another relocatee added, "At first the moving company was kind of rough with my things, but the man [relocation specialist] told them to act right and they did." In another positive review, a relocatee shared:

To be honest with you, the relocation lady was really nice and complimented me on my home and how I kept it up and decorated it. I appreciated that. It kind of showed me that she felt for my loss and respected me and my feelings. Poor folks, especially poor black folks, don't always get that kind of treatment from officials. There haven't been any problems getting money due you when it's needed either. No runaround at all.

\section{The relocation planning process}

The HCFCD first announced Project Hunting in 1990, and the first general public meeting did not take place until 1998. Eight general public meetings were held from June 11, 1998 to November 10, 2007. In addition, the HDCFC met with four community organizations: the Northeast Concerned Citizens Civic League in January 2006; the City of Houston's Land Assemblage Redevelopment Authority in November 2006; Houston Habitat for Humanity in May 2007, and the Houston Gardens Civic Club in November 2008.

The majority of post-2007 community-organization meetings were held with the Kashmere Gardens Super Neighborhood Council (KGSNC), a City of Houston geographically-designated area council whose shareholders meet to address community concerns. The HCFCD met with the KGSNC twenty-three times between August 2006 and March 2014.

The HCFCD also created a citizen advisory committee specifically for Project Hunting. This had representatives from the City of Houston's Parks Department, the Bayou Preservation Association (Houston's leading civil-society bayou ecological health and environmental amenity advocate), Harris County Board of Commissioners members, business owners, and, since the Hunting Bayou watershed extends outside Houston, political representatives from Galena Park and Jacinto City. USACE project documents state that there were no expressions of opposition to Project Hunting at any HCFCD-sponsored meeting. One potential cause of opposition may be the timelag between project conceptualization and construction. The HCFCD is sharing the costs of Project Hunting with the USACE, and reimbursements from the USACE to the HCFCD depend on congressional appropriations that come to the local level bit-by-bit, not all at once. This may cause discord with residents who would like the project to happen sooner rather than later. 
Many residents spoke of the length of the planning process, and that they had forgotten about it:

I was shocked when they came to tell me I might be losing my house. I think it was back in the early '90s when we [the neighborhood] first heard about the county fixing the flood problems around here. You heard about relocation ten years after that. When I finally did hear about the relocation, I was of the mind that the plans were not going to happen.

Another future relocator added, "It doesn't seem right to hold up people's lives like they have. You take forever to decide what to do, you tell people what's going to happen, and then you take forever in doing your own plan." A relocatee in favor of moving said: "I had been looking to move for a while and wanted them to hurry the hell up. My kids have moved away, and I am divorced, so I no longer needed or wanted to stay in my house. It took so long to actually be moved that I thought it wasn't going to happen. At first you're excited about a change, then you get all anxious waiting." A relocatee not in favor of moving noted:

For me, the waiting on hearing about the relocation was not much of a problem as I didn't believe they were going to do it [Project Hunting] in the first place. So I kind of put everything in the back of my mind. The communication you received was also spaced out, and I never did go to any of the community meetings the HCFCD said were held. But when their man finally came by and told me that the relocations were going to happen, it was like a punch to my stomach. I went to church in this neighborhood, I went to high school in this neighborhood, and I got family in this neighborhood. This has been my home forever, and even with the flooding problem I will miss living here.

Even where residents were in favor of relocation, the delays in implementation and the waiting caused anxiety. This was from fear of flooding, and from uncertainty about whether they would be relocated. Those who were not in favor of relocation tended to think optimistically that Project Hunting might not happen, so they disregarded communications from the HCFCD, receiving a shock when these arrived. It would be difficult to argue that either group have been 'made whole.'

\section{Health issues}

Numerous health disparities exist between peoples of color and the majority population in the United States (Gehlert et al. 2008; Levine et al. 2001). In the major urban relocations that have taken place since the HOPE VI program began, participants have been found to have poor health before relocation and worsened health after moving. While Kashmere Gardens is primarily a single-family home ownership community and public housing has traditionally been multi-family, homeowners have similar demographic characteristics to residents in public housing. One might then assume that their health concerns would be similar.

One relocatee had this to say about his mental state:

I'm not one to get depressed, but I sure do get mad about things. I honestly was pretty pissed off about being forced to move when I also heard that the neighborhood was being made safe for those who are staying. I had trouble sleeping because I was so mad, and when that burnt off, I guess I was anxious about the changes I had to deal with.

A Kashmere Gardens resident who has yet to be relocated said:

You're pretty up and down dealing with all this: the worrying, the being mad, and the feeling of being annoyed about just being bothered by these strangers who are taking away peoples' homes. You're not just mad about your own situation either. They are moving people that have been here for decades, away from their kids, and churches, and everybody they know. It's a wonder we 
haven't had more heart attacks in the neighborhood. The relocation (and its associated stress) is a bigger problem than the flooding.

One woman who seemed to be ambivalent about relocation said:

I don't know which has caused me more grief, the flooding or learning about having to be relocated. I honestly think I am too old to be dealing with either of them. I usually don't have problems sleeping, but lately that's been an issue. I get my blood pressure and heart rate checked pretty regularly over at the drug store, and their machine says there haven't been any changes. But I know I don't feel the same because of all the stress.

The relocation planning for each affected household aggravated some of those who wanted to be relocated as soon as possible. But relocation is just one part of the overall project, and each separate element and its associated funding requires approval not only at the local level by the HCFCD but at the federal level by the USACE, because it seeks to reimburse the HCFCD and cover certain Project Hunting costs. These approvals take time, as do unforeseen adjustments to the Project Hunting plan. Waiting for approvals and for further steps to be taken just heightened anxiety for relocatees.

One big difference between political ecology studies and the United States urban experience is the degree of resilience exhibited by those relocated. Longitudinal research has shown that after a while, people involuntarily relocated in the developing world display robust coping mechanisms and adapt to their new surroundings, alter agricultural and livelihood practices if necessary, and even perceive their mental and physical health to improve as time passes (Heming, Waley, and Rees 2001; McElwee 2006). In the developed world, and Kashmere Gardens appears to be an example, relocatees and those awaiting relocation speak more of deteriorating physical and mental health. This is understandable given that they are confronted with an exogenous force that has a big effect on their life. Perhaps the HCFCD and its analogues throughout the United States should carry out longitudinal health studies of flood-control infrastructure-project relocatees. Moving, whether a person wants to or not, can be mentally and physically draining, and having to deal with unfamiliar people (relocation specialists, movers, etc.) intensifies this. The HCFCD's use of specialists rather than engineers to oversee relocations seems to be beneficial. The relocation specialists end up being the faces of Project Hunting. The voluntarily and involuntarily relocated households spoke favorably about the relocation specialists, although some households voiced disapproval over not getting firm answers as quickly as desired.

\section{Conclusion}

While the Harris County Flood Control District and the Uniform Relocation Act frame issues of household 'wholeness' primarily in monetary terms, it is not surprising that households that have been relocated or will soon be relocated conceived of being 'whole' in many other ways. These include their desire to stay in the homes they love, in the neighborhood they love, or missing their neighborhood after they relocate. They have depression, anger, and uneasiness arising from the stress of knowing they will be relocated, and the uncertainties in the process. This indicated the HCFCD could provide counseling as part of its interactions with local residents. Attending to the mental and physical health of relocated households would give them time to adapt.

It is certainly a good idea to have experts that are not engineers in charge of the relocation. US Army Corps of Engineers personnel have exhibited notoriously bad 'people skills' and inflexibility where it leads project relocation efforts (Lythcott 2002). Having a local partner in charge of Project Hunting appears to be beneficial because the HCFCD can then use relocation specialists familiar with the Houston area and its various housing markets. These specialists are probably more empathetic to the stress that arises for someone leaving a home they love compared to a technical specialist concerned with financial compensation arrangements. A household's attachment to place cannot always be monetized, and being cognizant of the non-monetary concerns of households preparing to be relocated might lead to more equitable outcomes. 
It was not surprising to find discontent with the length of the planning process. Project Hunting was first proposed in 1990, and the first voluntary relocations did not happen until 2007. The HCFCD began construction in 2007, but it was not until 2014 that the HCFCD knew it would be eligible to have some of its costs reimbursed by the USACE. This 24 year interlude made it difficult for the HCFCD and affected Kashmere Gardens residents. The lag resulted from a congressional appropriations timetable not under the control of the HCFCD. The appropriate public agencies should shorten the timetable but not so much that it would leave insufficient time for community input. The HCFCD has relocated thousands of households throughout the greater Houston area, and HCFCD analogs across the country have done likewise.

This article was not written to critique Project Hunting. In fact, Project Hunting seems to be unique in trying to preserve a low-income minority neighborhood as opposed to destroying it to build something else. Unfortunately, recent legislative actions relating to USACE projects may result in changes to their project cost-benefit analyses that would prohibit further efforts like Project Hunting (Robertson and Schwartz 2015; Rogers et al. 2015). Also, new federal housing policies now favor more economically and racially integrated neighborhoods (Davis and Appelbaum 2015; de Vries 2017). This is important to keep in mind since climate change forecasts tell us which cities flooding will most likely affect, but certain neighborhoods will be more affected than others (Hunt and Watkiss 2011; Shearer 2012). Neighborhoods that planners intend to subject to relocation will be those that lack the political influence to negate relocation plans. We also know that the USACE, along with the Department of Housing and Urban Development, will be one of the leading federal agencies dealing with urban-floodplain management efforts that include community relocation (Anderson 2016; Shearer 2012). It is important to know how HUD and USACE regulations and responsibilities are intertwined.

A suitable framework can be crafted from different aspects of urban and political ecology studies. In all cases, powerful outside interests can disrupt environments, and planning involuntary relocations is just one such process. In Houston, even though the URA constrains the powers of the USACE and the HCFCD, involuntary relocation and its negative social effects remain. The HCFCD attempted to garner community input, and the majority of the community seems to agree that it is fine to relocate a few households. But could the affected households have been moved to existing housing in Kashmere Gardens? This is unlikely, since federal policy promotes moving relocated households away from poor neighborhoods, away from majorityminority neighborhoods, and away from any that are in or near floodplains. There are no examples of a relocated community where everyone agreed with all the outcomes of relocation efforts (Maldonado 2014).

There are two final recommendations:

(1) Public agencies should never assume all involuntarily relocated households can be satisfied. Communicating with representatives of legitimate organizations is not the same as communicating with the actual households subject to voluntary and involuntary relocation. Consider creating a group of representatives made up of households being relocated. Allow the households that are being relocated to say goodbye in a ceremonial, symbolic way to their neighborhood. Offer physical and mental health checkups to households both before and after relocation.

(2) Households subject to relocation should take it upon themselves to stay informed of developments, communicating with other affected households and sharing information. Pooling resources and hiring lawyers and appraisers familiar with public agency-sponsored relocation can improve knowledge of appeals to housing valuations and housing offers elsewhere. Affected households should not take lightly the stress that relocation induces; meaning personal and community 'care' is just as important as managing the logistical and financial aspects of relocation. 


\section{References}

Aecom Technical Services, Inc. 2014. Hunting Bayou flood risk management, Harris County, Texas. Draft General Reevaluation Report, Appendix 5, Economic Analysis. US Army Corps of Engineers Website [accessed March 9, 2015]

http://www.swg.usace.army.mil/Portals/26/docs/Planning/05_Hunting_Bayou_GRR-EA_Appendix05ECON.pdf

Anderson, E. 2016. Rising sea levels force U.S. to resettle Native American tribe. PBS News Hour: the Rundown Website. [accessed March 27 2016] http://www.pbs.org/newshour/rundown/rising-sealevels-force-u-s-to-resettle-native-american-tribe

Bedient, P. 2012. Lessons from Hurricane Ike. College Station, TX; Texas A\&M University Press.

Bullard, R.D. 2000a[1990]. Dumping in Dixie: race, class, and environmental quality. Third Edition. New York: Westview Press. Ch.1,2

Bullard, R.D. 2000b[1987]. Invisible Houston: the Black experience in boom and bust. College Station, TX: Texas A \& M Press.

Bunce, S. and G. Desfor. 2007. Introduction to "Political ecologies of urban waterfront transformations." Cities 24(4): 251-258.

Cernea, M.M. 2006. Poverty risks and national parks: policy issues in conservation and resettlement. World Development 34: 1808-1830.

City of Houston Planning and Development Department Public Policy Division. 2010. Kashmere Gardens Super Neighborhood Demographic and Income Profile.

Colchester, M. 1993. Pirates, squatters, and poachers: the political ecology of dispossession of the native peoples of Sarawak. Global Ecology and Biogeography Letters 3(4/6): 158-179.

Collins, T.W. 2010. Marginalization, facilitation, and the production of unequal risk: the 2006 Paso Del Norte floods. Antipode 42(2): 258-288.

Cunningham, M. K. 2004. An improved living environment? Relocation outcomes for HOPE VI relocatees. Urban Institute Metropolitan Housing and Communities Center. Washington DC.

Davis, J. H. and B. Appelbaum. 2015. Obama unveils stricter rules against segregation in housing. New York Times Website [accessed April 11 2017] https://www.nytimes.com/2015/07/09/us/hud-issuing-newrules-to-fight-segregation.html?_r=0

Davis, M. 1998. The ecology of fear. New York: Metropolitan.

de Vries, D.H. 2017. Historical waterscape trajectories that need care: the unwanted refurbished flood homes of Kinston's devolved disaster mitigation program. Journal of Political Ecology 24: 931-950.

Falk, W.W. 2004. Rooted in place: family and belonging in a southern Black community. New Brunswick: Rutgers University Press.

Feagin, J.R. 1988. Free enterprise city: Houston in political-economic perspective. New Brunswick: London.Rutgers University Press;

Gehlert, S., D. Sohmer, T. Sacks, C. Mininger, M. McClintock, and O. Olopade. 2008. Targeting health disparities: a model linking upstream determinants to downstream interventions. Health Affairs 27(2): 339-349.

Goetz, E. G. 2010. Better neighborhoods, better outcomes? Explaining relocation outcomes in HOPE VI. Cityscape 12: 5-32.

Griffiths, T. 2005. Indigenous peoples and the World Bank: experiences with participation. Moreton-inMarsh, UK: .Forest Peoples Programme.

Guest, G., K.M. MacQueen, and E.E. Namey. 2012. Applied thematic analysis. Thousand Oaks, CA: Sage.

Hagerman, C. 2007. Shaping neighborhoods and nature: urban political ecologies of urban waterfront transformations in Portland, Oregon. Cities 24(4): 285-297.

Harris County Flood Control District 2015a. HCFCD Website [accessed June 14 2015] About the District. www.hcfcd.org/about. 
Harris County Flood Control District 2015b. Hunting Bayou Watershed Overview. HCFCD Website [accessed June 14 2015] www.hcfcd.org/bayous-watersheds/harris-county-watersheds/hunting-bayou

Harris County Flood Control District 2015c. Project Hunting. HCFCD Website [accessed June 14 2015] www.hcfcd.org/projects-studies/hunting-bayou-projects-studies/project-hunting

Hartman, C.W. 1971. Relocation: illusory promises and no relief. Virginia Law Review 7(5): 745-817.

Heming, L., P. Waley, and P. Rees. 2001. Reservoir resettlement in China: past experience and the Three Gorges Dam. The Geographical Journal 167(3): 195-212.

Heynen, N. 2014. Urban political ecology I: the urban century. Progress in Human Geography 38(4): 598604. Academia

Hunt, A. and P. Watkiss. 2011. Climate change impacts and adaptation in cities. Climatic Change 104: 13-49.

Ivey, J. 2002. Tropical Storm Allison June 5-9, 2001. Presentation . Arlington, TX : American Society of Civil Engineers. March 27-30, 2002.

Jankowski, P., J. Philip, E. Chambers, J. Davis, R. Martinez, and A. Ellis. 2015. Global Houston: an assessment of Houston's ties to the world economy. Houston: Greater Houston Partnership.

Jha, A.K., R. Bloch and J. Lamond. 2011. Cities and flooding: a guide to integrated urban flood risk management for the $21^{\text {st }}$ century. Washington DC: World Bank.

Jha, A.K., T.W. Miner and Z. Stanton-Geddes. 2013. Building urban resilience: principles, tools, and practice. Washington DC: World Bank.

Johnson, D. 1989. Political ecology in the Upper Nile Valley: the twentieth century expansion of the pastoral 'common economy.' The Journal of African History 30(3): 463-486.

Keil, R. 2003. Urban political ecology. Urban Geography 24(8): 723-738.

Levine, R.S., J.E. Foster, R.E. Fullilove, M.T. Fullilove, N.C. Briggs, P.C. Hull, B.A. Husaini, and C.H. Hennekins. 2001. Black-white inequalities in mortality and life expectancy, 1933-1999: Implications for healthy people 2010. Public Health Reports 116(5): 474-483.

Lythcott, M. J. 2002. Neighborhood relocation: community issues, existing options and new ideas. Prepared for the Second National People of Color Environmental Leadership Summit—Summit II, October 23, Washington DC.

Maldonado, J.K. 2014. A multiple knowledge approach for adaptation to environmental change: lessons learned from coastal Louisiana's tribal communities. Journal of Political Ecology 21: 61-82.

Manjarrez, C.A., S.J. Popkin and E. Guernsey. 2007. Poor health: adding insult to injury for HOPE VI families. Washington DC: Urban Institute Metropolitan Housing and Communities Center.

Martin. K.S. 1983. Blight, redevelopment and relocation: a recurring pattern under the Uniform Relocation Act. UMKC Law Review 51(1): 107-126.

McElwee, P.D. 2006. Displacement and relocation redux: stories from Southeast Asia. Conservation and Society 4: 396-403.

Moran, C. 2010. Caught in the path of expansion. Houston Chronicle. May 2, 2010.

Namey, E.E., G. Guest, L. Thairu, and L. Johnson. 2008. Data reduction techniques for large qualitative data sets. In G. Guest and K.M. MacQueen (eds.) Handbook for team-base qualitative research. Lanham, MD: AltaMira Press.

National Academy of Sciences. 2006. Coastal hazards: highlights of National Academies reports. Washington DC: National Academy of Sciences.

O'Neill, K. 2006. Rivers by design: state power and the origins of U.S. flood control. Durham NC: Duke University Press.

Port of Houston Authority. www.portofhouston.com.

Roberts, N.A. 1973. Homes, roadbuilders and the courts: highway relocation and judicial review of administrative action. Southern California Law Review 46: 51-96. 
Robertson, C. and J. Schwartz. 2015. Decade after Katrina, pointing finger more firmly at Army Corps. New York Times Website [accessed May 23, 2015] http://www.nytimes.com/2015/05/24/us/decade-afterkatrina-pointing-finger-more-firmly-at-army-corps.html? $\mathrm{r}=0$

Rogers, J.D., G.P. Kemp, H.J. Bosworth and R.B. Seed. 2015. Interaction between the U.S. Army Corps of Engineers and the Orleans Levee Board preceding the drainage canal wall failures and catastrophic flooding of New Orleans in 2005. Water Policy 17 (4) 707-723.

Rohe, W.M. and S. Mouw. 1991. The politics of relocation: the moving of the Crest Street community. Journal of the American Planning Association 57(1): 1-18.

Rubenstein, J.M. 1988. Relocation of families for public improvement projects: lessons from Baltimore. Journal of the American Planning Association 54(2): 185-196.

Saldaña, J. 2012. The coding manual for qualitative researchers. Thousand Oaks: Sage.

Saucier, H. April 10, 2003. Facts about Harris County Flood Control District acquisition, buyouts and relocation. Houston Chronicle Website [accessed March 9 2015] www.chron.com/news/article/Factsabout-Harris-County-Flood-Control-District-2127623.php

Scheuler, T. 1987. The importance of imperviousness. Watershed Protection Techniques 1(3): 100-111.

Scheuler, T., L. Fraley-McNeal and K. Cappiella. 2009. Is impervious cover still important? Review of recent research. Journal of Hydrologic Engineering 14(4): 309-315.

Scudder, T. 1993. Development-induced relocation and refugee studies: 37 years of change and continuity among Zambia's Gwembe Tonga. Journal of Refugee Studies 6(2): 123-152.

Shearer, C. 2012. The political ecology of climate adaptation assistance: Alaska natives, displacement, and relocation. Journal of Political Ecology 19: 174-183.

Smith, L. 2002. The urban political ecology of water in Cape Town, South Africa. Background Research Series. Johannesburg: Municipal Services Project, Queens University Graduate School of Public and Development Management.

Stack, C. B. 1974. All our kin: strategies for survival in a Black community. New York: Basic Books.

Sterne, R. S., B. Kaufman, and G. Rubenstein. 1977. Personal interests and client satisfaction with urban renewal. The Ohio Journal of Science 77(6): 249-255.

Swyngedouw, E. and N. Heynen. 2003. Urban political ecology: justice and politics of scale. Antipode 35: 898-918. Introduction to Special Issue. Researchgate

United Nations Office for Disaster Risk Reduction. 2012. Making cities resilient. New York: UNISDR.

United States Census Bureau. Houston (city), Texas Quick Facts. UCSB Website [accessed June 14 2015] quickfacts.census.gov/qfd/states/48/4835000.html

U.S. Army Corps of Engineers. 1998. The history of the US Army Corps of Engineers. Alexandria, VA: Office of History, USACE Headquarters.

United States Department of Housing and Urban Development. 2015a. HUD Website [accessed March 9, 2015]. http://portal.hud.gov/hudportal/HUD?src=/program_offices/comm_planning/library/relocation

United States Department of Housing and Urban Development 2015b. HOPE VI. HUD Website [accessed March 9 2015] http://www.hud.gov/offices/pih/programs/ph/hope6/about/description.cfm.

World Bank. 2010. Safer homes, stronger communities: resources for reconstructing housing and communities after natural disasters. Washington DC: World Bank.

Yosso, T.J. 2006. Whose culture has capital? A critical race theory discussion of community cultural wealth. Race, Ethnicity, and Education 8(1): 69-91.

Zhang, Y. 2010. Residential housing choice in a multihazard environment: implications for natural hazards mitigation and community environmental justice. Journal of Planning Education and Research 30(2): $117-131$. 